\title{
PREVALENSI BENDA ASING PADA ESOFAGUS DAN BRONKUS DI BAGIAN/SMF THT-KL FK UNUD/ RSUP SANGLAH DENPASAR TAHUN 2010-2012
}

${ }^{1}$ Gde Bagus Rizky Kornia, ${ }^{2} d r$. Sari Wulan Dwi Sutanegara, Sp.THT-KL, ${ }^{3} d r$. I Wayan Sucipta, Sp.THT-KL

${ }^{1}$ Program Studi Pendidikan Dokter, Fakultas Kedokteran Universitas Udayana

${ }^{2}$ Bagian/SMF IImu Kesehatan Telinga Hidung Tenggorokan Fakultas Kedokteran Universitas Udayana / Rumah Sakit Umum Pusat Sanglah, Denpasar

ghz.evo@gmail.com

\section{ABSTRAK}

Kebanyakan masyarakat tidak terlalu menghiraukan masalah benda asing yang masuk kedalam organ tubuh mereka, mereka datang ke rumah sakit atau ke dokter setelah benda asing tersebut menunjukkan gejala-gejala yang serius sehingga membuat pasien merasa tidak nyaman atau merasa kesakitan. Penelitian ini bertujuan untuk mengetahui prevalensi benda asing di esofagus dan bronkus di Bag/SMF THT-KL FK UNUD/ RSUP Sanglah Denpasar Tahun 2010-2012. Penelitian ini bersifat deskriptif dengan desain penelitian cross sectional (retrospektif).

Dari 56 kasus penelitian yang didapat sebagian besar penderita berjenis kelamin laki-laki sebanyak 31 orang $(55,4 \%)$, berdasarkan umur kelompok balita merupakan yang paling banyak adalah sebanyak 16 orang $(28,6 \%)$, sedangkan uang logam merupakan jenis benda asing yang paling banyak ditemukan sebanyak 17 kasus $(30,4 \%)$, dan benda asing terbanyak adalah benda asing organik yaitu sebanyak 30 kasus $(53,6 \%)$, terakhir menurut lokasi benda asing yang terbanyak berada esofagus yaitu sebanyak 46 kasus $(82,1 \%)$.

Perlu edukasi untuk orang tua agar lebih mengawasi anak-anaknya saat bermain dengan benda yang berpotensial non-organik seperti uang logam masuk ke dalam rongga tubuh terutama esofagus.

Kata kunci: Benda asing, rsup sanglah ,esofagus dan bronkus.

\section{Prevalence of foreign body objects in the esophagus and bronchus at the Department of Otolaryngology Faculty of Medicine UNUD/RSUP Sanglah Denpasar in 2010-2012.}

\section{ABSTRACT}

Most people have little attention on the problem of foreign bodies that enter organs, patients come to the hospital or to the doctor after the foreign bodies showed serious symptoms that make patients feel uncomfortable or feel pain. The purpose of this study is to obtain the characteristics of patients with foreign body objects in the esophagus and bronchus in the Department of Otolaryngology Faculty of Medicine UNUD/RSUP Sanglah Denpasar in 2010-2012. This research is a descriptive study with cross sectional (retrospective) design.

From the 56 cases obtained, the majority of patients were male (31 person, 55,4\%), and based on the age group, most of the patients are under 5 years of age ( 16 person, 28,6\%). Most of the foreign body that was found are categorized organic (30 case, 50,36\%). Metal coin as the majority foreign body acquired (17 case, 30,4\%). According to the location of obstruction, the esophagus was the most frequent location that had a foreign body with 46 cases $(82,1 \%)$.

It's recommended for parents to pay attention to their children while playing with the non-organic objects like metal coin potensial in entering body carity especially esophagus

Keywords: Foreign body, rsup sanglah, esophageal and bronchus. 


\section{PENDAHULUAN}

Corpus alienum atau benda asing adalah masalah kesehatan keluarga yang biasanya terjadi pada anak - anak. Benda - benda asing yang sering ditemukan biasanya makanan, mainan, dan peralatan rumah tangga yang kecil. Diagnosis pada pasien sering terlambat karena penyebab biasanya tidak terlihat dan gejalanya tidak spesifik dan sering terjadi kesalahan diagnosis pada awalnya. Pada orang dewasa, benda asing yang tersangkut dapat berupa makanan atau bahan yang tidak dapat dicerna, seperti biji buah-buahan, gigi palsu, tulang ikan atau potongan daging yang melekat pada tulang. ${ }^{1}$

Benda asing yang tersangkut di saluran cerna dapat terjadi pada semua umur tetapi merupakan masalah utama pada anak usia 6 bulan sampai 6 tahun dan benda asing ini dapat tersangkut pada tiap lokasi di esofagus. Biasanya benda asing yang sering di esofagus pada anak yaitu uang logam. Benda asing dalam esophagus dapat menyebabkan penyumbatan dan penekanan ke jalan nafas. ${ }^{1}$ Benda asing pada saluran napas dapat terjadi pada semua umur terutama anak-anak karena anak-anak sering memasukkan benda ke dalam mulutnya bahkan sering bermain atau menangis pada waktu makan sehingga dapat tersangkut di laring, trakea atau bronkus. Tempat dimana tersangkutnya benda asing tergantung pada ukuran dan bentuk benda asing tersebut. Benda asing yang kecil dapat masuk melewati laring ke trakea atau bronkus. Aspirasi benda asing lebih sering terjadi pada anakanak daripada orang dewasa, terbanyak pada usia 3 tahun. Aspirasi sering terjadi akibat anak meletakkan benda di dalam mulut sambil bermain dan tiba-tiba menghirup nafas. ${ }^{1}$

Berdasarkan data-data diatas, penelitian tentang prevalensi benda asing di esofagus dan bronkus di RSUP Sanglah Denpasar belum pernah dilakukan.
Oleh karena itu, peneliti tertarik untuk menelitinya.

\section{METODE PENELITIAN}

Penelitian ini merupakan penelitian deskriptif dengan desain cross sectional study, dimana peneliti menjalankan pengumpulan data satu kali berdasarkan survey rekam medis secara retrospektif yang akan menilai gambaran karakteristik benda asing di esofagus dan bronkus. Penelitian dilaksanakan pada bulan November 2013 dengan mengambil data dari rekam medis RSUP Sanglah Denpasar tahun 2010-2012. Data yang terkumpul dalam penelitian diolah dengan menggunakan program SPSS dan dianalisis secara deskriptif kemudian ditampilkan dalam bentuk tabel frekuensi.

Sampel pada penelitian ini adalah seluruh pasien yang didiagnosa dengan benda asing di esofagus dan bronkus di Bagian/SMF IImu THT-KL RSUP Sanglah Denpasar dan Rekam Medis RSUP Sanglah Denpasar tahun 2010-2012.

Pengumpulan data dilakukan berdasarkan jenis kelamin, kelompok usia, tahun, jenis benda asing, dan lokasi benda asing.

\section{HASIL PENELITIAN}

Tercatat sebanyak 56 penderita masuknya benda asing di esofagus dan bronkus di Bag/SMF THT-KL FK UNUD/ RSUP Sanglah Denpasar Tahun 20102012. Berdasarkan jenis kelamin seperti yang ditunjukkan pada tabel 1 , didapatkan mayoritas penderita berjenis kelamin laki laki $(55,4 \%)$. Tabel 2 menyajikan angka kejadian berdasarkan tahun. Tabel 2 menunjukkan jumlah terbanyak adalah pada tahun 2011 \& 2012 (33,9\%). Berdasarkan tabel 3, kelompok umur terbanyak adalah kelompok umur balita 0-5 tahun (28,6\%).

Tabel 1. Distribusi Penderita Berdasarkan Jenis Kelamin

\begin{tabular}{lcc}
\hline Jenis kelamin & Jumlah $(\mathrm{n})$ & Persentase $(\%)$ \\
\hline Laki - laki & 31 & 55,4 \\
Perempuan & 25 & 44,6 \\
& & \\
\hline Total kasus & 56 & 100 \\
\hline
\end{tabular}

Tabel 2. Distribusi Penderita Berdasarkan Tahun

Tahun Jumlah (n) Persentase (\%)




\section{Total kasus}

56

100

Tabel 3. Distribusi Penderita Berdasarkan Kelompok Umur

\begin{tabular}{lcc}
\hline Kelompok Umur & Jumlah (n) & Persentase (\%) \\
\hline Masa balita (0 - 5 thn) & 16 & 28.6 \\
Masa kanak-kanak (5-11 thn) & 9 & 16.1 \\
Masa remaja Awal (12 - 16 thn) & 0 & 0 \\
Masa remaja Akhir (17 - 25 thn) & 6 & 10.7 \\
Masa dewasa Awal (26 - 35 thn) & 4 & 7.1 \\
Masa dewasa Akhir (36 - 45 thn) & 5 & 8.9 \\
Masa Lansia Awal (46 - 55 thn) Masa & 2 & 3.6 \\
Lansia Akhir (56 - 65 thn) & 8 & 14.3 \\
Masa Manula (65 - sampai atas) & 6 & 10.7 \\
& & \\
\hline Total kasus & 56 & 100 \\
\hline
\end{tabular}

Tabel 4. Distribusi Penderita Berdasarkan Jenis Benda Asing

\begin{tabular}{lcc}
\hline Jenis Benda Asing & Jumlah $(\mathrm{n})$ & Persentase (\%) \\
\hline Anggur & 1 & 1.8 \\
Biji silik & 1 & 1.8 \\
Biji srikaya & 1 & 1.8 \\
Daging babi & 2 & 3.6 \\
Gigi palsu & 5 & 8.9 \\
Jarum pentul & 1 & 1.8 \\
Jarum sonde & 1 & 1.8 \\
Kacang & 3 & 5.4 \\
Peluit & 1 & 1.8 \\
Semut & 1 & 1.8 \\
Soda api & 1 & 1.8 \\
Tahu isi daging & 1 & 1.8 \\
Tulang ayam & 13 & 23.2 \\
Tulang babi & 2 & 3.6 \\
Tulang bebek & 1 & 1.8 \\
Tulang ikan & 3 & 5.4 \\
Tulang kambing & 1 & 1.8 \\
Uang logam & 17 & 30.4 \\
\hline Total kasus & 56 & 100 \\
\hline
\end{tabular}

Tabel 5. Distribusi Penderita Berdasarkan Benda Asing

\begin{tabular}{lcc}
\hline Benda Asing & Jumlah (n) & Persentase (\%) \\
\hline Benda Asing Organik & 30 & 53.6 \\
Benda Asing Non-Organik & 26 & 46.4 \\
\hline Total kasus & 56 & 100 \\
\hline
\end{tabular}


Uang logam merupakan jenis benda asing yang paling banyak ditemukan $(30,4 \%)$ seperti yang ditunjukkan pada tabel 4. Sedangkan berdasarkan tabel 5 , benda asing yang paling banyak adalah benda asing organik (53,6\%). Berdasarkan tabel 6 didapati bahwa lokasi benda asing yang terbanyak berada pada esofagus $(82,1 \%)$.

Tabel 6. Distribusi Penderita Berdasarkan Lokasi Benda Asing

\begin{tabular}{lcc}
\hline Lokasi Benda Asing & Jumlah (n) & Persentase (\%) \\
\hline Esofagus & 46 & 82.1 \\
Bronkus & 10 & 17.9 \\
& & \\
\hline Total kasus & 56 & 100 \\
\hline
\end{tabular}

\section{PEMBAHASAN}

Berdasarkan tabel 1 didapati bahwa jenis kelamin laki-laki merupakan sampel terbanyak yaitu sebanyak 31 orang $(55,4 \%)$ dan sampel perempuan sebanyak 25 orang $(44,6 \%)$. Hal ini sesuai dengan penelitian di Departemen THT-KL FKUI RSCM Sub Departemen Bronkoesofagologi dari bulan Januari 2002 sampai Agustus 2004, tercatat 43 kasus. Penderita terbanyak berusia, lebih sering pada anak lakilaki. ${ }^{12}$

Berdasarkan tabel 2 didapati bahwa penderita masuknya benda asing pada esofagus dan bronkus menurut tahun kejadiannya yang terbanyak adalah pada tahun 2011 \& 2012 sebanyak 19 kasus (33,9\%). Sedangkan yang paling sedikit adalah pada tahun 2010 sebanyak 18 kasus $(32,1 \%)$.

Berdasarkan karakteristik kelompok umur pada tabel 3 didapati bahwa penderita masuknya benda asing dengan kelompok balita merupakan yang paling banyak adalah sebanyak 16 orang (28,6\%). Sedangkan yang paling sedikit adalah kelompok lansia awal sebanyak 2 orang (3,6 \%). Rovin dkk mengungkapkan aspirasi benda asing merupakan penyebab 5\% kematian mendadak pada anak berumur dibawah 4 tahun, sedangkan umur dibawah 1 tahun meningkat menjadi $10 \%$. Kasus aspirasi benda asing lebih sering dijumpai pada anak laki-laki. ${ }^{13}$ Menurut Freud, tahap oral (mulut) ini berlangsung selama 18 bulan pertama kehidupan. Mulut merupakan sumber kenikmatan utama. Dua macam aktivitas oral di sini, yaitu menggigit dan menelan makanan, merupakan prototype bagi banyak ciri karakter yang berkembang di kemudian hari. Perkembangan kognitif pada anak usia 6-12 bulan, pada tahap awal semuanya masuk ke dalam mulut. Terkadang, benda-benda baru diambil, diperiksa, dipindahkan dari tangan ke tangan, dibanting, dijatuhkan, dan kemudian dimasukkan ke dalam mulut. Pada usia 12-18 bulan dimana anak-anak sudah mulai berjalan dan mengenali benda-benda yang dilihatnya. Pada anak anak, yang mempunyai resiko tinggi adalah yang berumur 14-18 bulan pada saat fase oral dan ketika gigi molar pertama baru tumbuh. Pada anak-anak yang akan tumbuh gigi mulai akan memasukkan barang yang bisa dicapainya ke dalam mulut. Benda asing yang di dalam mulut masuk ke dalam tubuh bisa terjadi pada saat menangis, tertawa, ataupun pada saat makan tersedak. ${ }^{14}$ Maka dari itu banyak kasus ditemukan masuknya benda asing ke dalam tubuh sering terjadi pada anak-anak.

Berdasarkan tabel 4 didapati bahwa penderita masuknya benda asing dengan jenis-jenis benda asing yang di dapati yaitu, uang logam merupakan jenis benda asing yang paling banyak ditemukan sebanyak 17 kasus $(30,4 \%)$. Sedangkan benda asing yang paling sedikit ditemukan adalah anggur, biji silik, biji srikaya, jarum pentul, jarum sonde, peluit, semut, soda api, tahu isi daging, tulang bebek, tulang kambing yaitu masing-masing sebanyak 1 kasus $(1,8 \%)$. Uang logam merupakan salah satu jenis benda eksogen non-organik. Benda asing uang logam di esofagus bukan keadaan gawat darurat, namun uang logam tersebut harus 
dikeluarkan sesegera mungkin dengan persiapan tindakan esofagoskopi yang optimal untuk mencegah komplikasi. ${ }^{1}$

Damghani mendapatkan 123 kasus selama 7 tahun di Iran. Dari jumlah kasus tersebut didapatkan yang paling sering adalah uang logam untuk anak-anak dan tulang untuk orang dewasa. ${ }^{15}$ Hasilnya sama dengan penelitian yang dibuat oleh Koirala di Manipal Teaching Hospital di Nepal, dari 63 kasus didapatkan bahwa yang paling sering adalah uang logam untuk anak-anak $(82,1 \%)$ dan tulang untuk orang dewasa $(91,4 \%){ }^{16}$

Berdasarkan tabel 5. didapati bahwa penderita masuknya benda asing dengan kategori benda asing yang paling banyak adalah benda asing organik yaitu sebanyak 30 kasus (53,6\%). Sedangkan benda asing non-organik sebanyak 26 kasus (46,4\%). Benda asing, yang seharusnya tidak ditemukan didalam tubuh yang normal yaitu, berupa benda asing organik maupun anorganik bisa berbahaya jika dibiarkan berlama-lama di dalam tubuh. Misalnya pada esofagus bisa menyebabkan rasa nyeri dan tidak bisa menelan, sedangkan pada bronkus bisa menyebabkan kematian akibat sumbatan jalan nafas. Rina MT mendapatkan dari 101 kasus aspirasi benda asing organik, yang paling sering adalah kacang tanah kemudian diikuti biji-bijian dan tulang ayam. ${ }^{17}$

Berdasarkan tabel 6 didapati bahwa lokasi benda asing yang terbanyak berada pada esofagus yaitu sebanyak 46 kasus $(82,1 \%)$, sementara pada bronkus 10 kasus (17,9\%). Terbanyak ada pada esofagus, tahap oral (mulut) ini berlangsung selama 18 bulan pertama kehidupan. Mulut merupakan sumber kenikmatan utama, karena seringnya anak-anak pada umur 6 bulan mulai memasukkan barangbarang yang bisa dicapainya/dipegang dalam tangan masuk kedalam mulut. Dan benda asing yang ditemukan berupa uang logam, jarum, potongan biji durian, gigi palsu, jarum pentul, cincin, dan lain-lain. Penelitian ini mencatat pada bronkus banyak ditemukan pada bronkus kanan yaitu sebanyak 2 kasus, sedangkan sisanya tidak disebutkan di bronkus bagian mana. Bronkus utama kanan lebih pendek dari bronkus utama kiri. Masing-masing panjangnya kira-kira 2,5 cm dan $5 \mathrm{~cm}$ serta membentuk sudut $25^{\circ}$ dan sudut $45^{\circ}$ dengan garis tengah. Bronkus utama kanan hampir lurus dengan trakea sehingga benda asing eksogen yang masuk ke bronkus akan lebih mudah masuk ke bronkus utama kanan, dibanding dengan bronkus utama kiri. Faktor lain yang mempermudah masuknya benda asing ke dalam bronkus utama kanan adalah kerja otot trakea yang mendorong benda asing itu kearah kanan. Selain itu udara inspirasi ke dalam bronkus utama kanan lebih besar dibandingkan dengan udara inspirasi ke bronkus utama kiri. ${ }^{18}$

\section{PENUTUP}

Sebagian besar penderita berjenis kelamin lakilaki (55.4\%) dan jumlah kasus terbanyak pada tahun 2011 \& 2012 (33.9\%). Kelompok umur terbanyak adalah pada kelompok balita yaitu umur 0-5 tahun (28.6\%) dengan jenis benda asing yang paling banyak ditemukan adalah uang logam (30.4\%). Benda asing organic merupakan yang terbanyak (53.6\%) dan lokasi yang paling banyak ditemukan adalah pada esofagus (82.1\%)

Dari penelitian ini, dapat kami sarankan bagi tenaga-tenaga medis seperti dokter, dan paramedis, dapat memberikan penyuluhanpenyuluhan tentang bahayanya benda asing yang masuk ke dalam tubuh, khususnya memberikan informasi yang lebih kepada orang tua yang mememiliki anak yang masih dibawah lima tahun bahwa sangat bahaya membiarkan anak-anak bermain/memegang sendiri bendabenda kecil yang dapat di masukkan ke mulutnya tanpa pengawasan orang tua.

\section{DAFTAR PUSTAKA}

1. Yunizaf, M., 2007. Benda Asing di Esofagus. Dalam : Buku Ajar Ilmu Kesehatan Telinga Hidung Tenggorokan Kepala Leher. $6^{\text {th }}$ ed. Jakarta : FK UI, 299- 301.

2. Karnadihardja W. Esofagus dan diafragma. In: Sjamsuhidayat, R. Buku Ajar Ilmu Bedah Sjamsuhidajat-de Jong, Edisi3, Jakarta : EGC. 1996 Hal 512 -513

3. Siegel LG. Penyakit Jalan Nafas Bagian Bawah, Esofagus, dan Mediastinum. Dalam : 
BOIES Buku Ajar penyakit THT. Editor: Adam GL, Higler PA. Edisi 6. Jakarta : EGC. 1997 Hal. 458

4. Mansjoer, Arif dkk. Kapita Selekta Kedokteran, Jakarta: Media Aesculapius. 2001 Hal. 135

5. Kartika, Heni. 2007. Bronchoesophagology. Available at www.wordpress.com. di akses tanggal: 25 November 2013

6. Hadjat, Fachri. Penyakit dan kelainan esophagus, In: Soepardi, Eflaty A, Iskandar, N. Buku Ajar Ilmu Kesehatan Telinga Hidung Tenggorok Kepala dan Leher Edisi Ke 6. Jakarta : Balai Penerbit FKUI. 2008. Jakarta : Balai penerbit FKUI. Hal. 285

7. Santoso, Budi. 2009. Benda Asing di Esofagus. avaliable at www. Oncologychannel.com. diakses tanggal : 25 November 2013

8. Sugito,Tarigan,H.M.M., Soeroso, L.S., 1992. Benda Asing di Saluran Napas. Bagian Ilmu Penyakit Paru FK USU/RS Dr. Pringadi. Medan.

9. Perkasa, M.F., 2009. Ekstraksi Benda Asing Laring (Rotan) dengan Neuroleptic Anesthesia. Medicinus, 22(2): 58-60.

10. Fitri, F., dan Pulungan, M.R., 2012. Ekstraksi Benda Asing (Kacang Tanah) di Bronkus dengan Bronkoskop Kaku. Bagian Ilmu Kesehatan Telinga Hidung
Tenggorok - Bedah Kepala Leher. Fakultas Kedokteran. Universitas Andalas Padang - Indonesia.

11. Saragih, A.R., dan Aliandri, 2007. Benda Asing Kacang di Trakea. Majalah Kedokteran Nusantara, 40(1): 74-80.

12. Tamin S, Hadjat F, Abdillah F. Penatalaksanaan aspirasi benda trakeobronkial dengan berbagai manifestasi klinis. Med J ORLI 2005;35: 16-25.

13. Rovin $D$, Rodgers $M$. Pediatric foreign body aspiration. Ped in review. 2000;21(3):86-90.

14. Needlman, R.D., 2000. Pertumbuhan dan Perkembangan. Dalam : Nelson IImu Kesehatan Anak. Vol 1. Jakarta : EGC, 53;55.

15. Damghani M, Halavati N, Motamedi N. Foreign body in the upper airway and oesophagus: A seven years study from Iran. J Pak Med Assoc. 2011;61(9):859862.

16. Koirala K, et al. Foreign body esophagus in children and adults. NJMS. 2012;1(1):42-4

17. Rina $M T$, Quintos R. Pediatric rigidbronchoscopy for foreign body removal.Phillipp J Otolaryngol Head Neck Surg 2009;24 (1): 39-41.

18. Maisel, R.H., 1997. Trakeostomi. Dalam : Effendi, H. \& Santoso, R.A.K (eds). 1997. BOIES Buku Ajar Penyakit THT. 6 th ed. Jakarta : EGC, 475-476. 